\title{
Methodological Approaches to Studies on the Pancreatic Islets
}

\author{
The Minkowski Award Lecture delivered on September 18, 1969 before the European \\ Association for the Study of Diabetes at Montpellier, France
}

\author{
Bo Heuluman
}

\author{
Department of Histology, University of Umea, Umea, Sweden
}

Received: October 16, 1969

\begin{abstract}
Summary. With a total volume of only a few per cent of the whole gland the mammalian endocrine pancreas is disporsed in a great number of islets of Langerhans. Studies of this endocrine organ are further complicated by the fact that each islet is composed of cells representing different endocrine functions. The present communication deals with some attempts to overcome these analytical difficulties by the following oxperimental approaches: A) The observation of a strict balance between the number of large and small islets made it possible to introduce rapid mothods for estimation of the total islet volume. It was found necessary meraly to count the number of large islets in pancreatic sections taken at regular intervals. There was also a linear relationship between the total
\end{abstract} islet volume and the number of long islet intercepts obtained by scanning sections with parallel lines. B) Attempts were made to identify the different types of islet cells by restaining thin paraffin sections after initial silver impregnation. Most important for the final success was the elaboration of a technique which gave a consistent argyrophilia in some islet calls, and the observation that these silver deposits could be removed by oxidation in potassium permanganate. It is now well established that the pancreatic islets contain $\alpha_{1}, \alpha_{2}$ and $\beta$-cells as well as some cells which lack discernible granules both in the light and electron microscope. C) Evaluation of how various substances affect insulin release was simplified by the introduction of a system in vitro employing a single islet microdissected from an obese-hyperglycaemic mouse. This technique allowed both a description of insulin release in terms of islet weight, and a correlation of the rate of insulin secretion with other metabolic events in the $\beta$-cells. The amount of insulin released during $30 \mathrm{~min}$ was found to be about one per thousand of the islet dry weight, or less than one per cent of the $\beta$-cell content of insulin. The rate of insulin secretion was significantly enhanced by increasing the movements of the incubation medium by shalking. A water extract of the $\alpha_{1}$-cells served as an effective inhibitor of insulin release. $D$ ) $\mathrm{A}$ combined approach in vivo and in vitro was found to provide a useful systern for analyzing how the $\beta$-cell levels of glycolytic intermediates and cofactors were related to the rate of insulin secretion. After the freeze-dried pancreas sections had been exposed to formaldehyde vapours and refixed in Bouin's solution, the islet cells could be identified by silver impregnation and restaining. The sulphonylurea-stimulation of insulin release was found to be asso-

The author gratefully acknowledges the privilege of many years of stimulating collaboration with the senior members of the diabetes research group in Uppsala (Drs. Brolin, Hellerström, Petersson and Westman) and Umea (Drs. Danielsson, Falkmer, IdahI, Lernmark and Täljedal). Financial support from the Swedish Medical Research Council $(12 \mathrm{x}-562)$ and the United States Public Health Service (AM - 05759 and AM - 12535) has been of the utmost importance in making possible the studies reported in the present lecture. ciated with a significant depression of the $\beta$-cell content of ATP and glycogen. There was, on the other hand, a striking accumulation of fructose-1.6-diphosphate and other intermediates of glucose above this metabolic stage when insulin secretion was inhibited either by epinephrine or diczoxide or by omission of $\mathrm{Ca}^{2+}$. These data were tentatively interpreted as indicating the existence of a rate limiting step in $\beta$-cell glycolysis of direct significance for regulation of insulin release. This control site might be the sequence phosphoglyceraldehyde dehydrogenasephosphoglycerate kinase.

Approches méthodologiques à des études sur les ilots pancréatiques.

Résumé. Avec un volume total représentant seulement quelques pour cent de la glande entière, le pancréas endocrine des mammifères est dispersé en une grande quantité d'îlots de Langerhans. L'étude de cet organe est en outre compliquéa par le fait que chaque îlot est composé de cellules représentant des fonctions endocrines variées. Le présent rapport traite des tentatives effectuées pour résoudre ces difficultés d'analyse en utilisant les méthodes suivantes: $A$ ) L'observation d'un équilibre strict entre le nombre d'îlots grands et petits a rendu possible l'introduction de procédés rapides pour l'estimation du volume insulaire total. Nous avons jugé utile de compter seulement le nombre de grands îlots des coupes pancréatiques prises à intervalles réguliers. Il y avait aussi une relation linéaire entre le volume insulaire total et le nombre d'intersections longues des îlots obtenues par exploration des coupes selon des lignes parallèles. $\bar{B}$ ) On a essayé d'identifier les diverses sortes de cellules insulaires, en recolorant de minces coupes de paraffine, après une imprégnation initiale d'argent. Le plus important pour obtenir un résultat valable fut l'élaboration d'une technique produisant une argyrophilie stable dans certaines cellules insulaires et l'observation que ces précipités d'argent pouvaient être supprimés par oxydation au permanganate de potassium. Il est aujourd'hui bien établi, que les îlots de Langerhans contiennent des cellules $\alpha_{1}, \alpha_{2}$ et $\beta$ ainsi que certaines cellules sans granules perceptibles même au microscope électronique. $O$ ) L'évaluation des effets directs de substances variées sur la libération d'insuline, fut simplifiée par l'introduction d'un système in vitro, se servant d'un seul îlot microdisséqué d'une souris obèse-hyperglycémique. Cette technique a permis non seulement une description de la libération d'insuline en fonction du poids insulaire, mais encore une corrélation entre l'insulino-sécrétion et d'autres évènements métaboliques dans les cellules $\beta$. La quantité d'insuline sécrétée pendant $30 \mathrm{~min}$ se trouvait être approximativement un pour mille du poids sec des îlots ou moins d'un pour cent du contenu d'insuline de la cellule $\beta$. $L_{a}$ vitesse de l'insulino-sécrétion fut significativement augmentée par agitation du milieu d'incubation. Un extrait aqueux des cellules $\alpha_{1}$ a servi d'inhibiteur effectif pour la libération d'insuline. $D$ ) Une tentavive d'analyse 
à la fois in vivo et in vitro s'est avérée représenter une méthode propre à déterminer la corrélation entre les taux bêta-cellulaires des intermédiaires de la glycolyse et des co-facteurs et la vitesse de la sécrétion insulinique. Après avoir exposé les coupes pancréatiques aux vapeurs d'aldéhyde formique, on les a refixées dans une solution de Bouin. Puis les cellules insulaires pouvaient être identifiées à l'aide d'imprégnation d'argent et de recoloration. La stimulation de la libération d'insuline par les sulfonylurées, était accompagnée d'un abaissement significatif du contenu. en ATP et en glycogène de la cellule $\beta$. On a trouvé, d'autre part, une accumulation frappante de fructose-1.6-diphosphate et d'autres intermédiaires du glucose avant cette étape métabolique pendant une inhibition de la sécrétion insulinique par l'adrénaline ou le diazoxide ou par l'omission de $\mathrm{Ca}^{2+}$. Les données présentes furent interprétées comme l'annonce de l'existence d'un point contrôlant la glycolyse de la cellule $\beta$ et en même temps dirigeant Ia libération d'insuline. Ce point de contrôle pourrait être la séquence de la phosphoglycéraldéhyde déshydrogénase-phosphoglycérate kinase.

Methodische Möglichkeiten für Untersuchungen der Pankreas-Inseln

Zusammenfassung. Mit einem Gesamtvolumen von nur wenigen Prozenten der ganzen Drüse ist das endokrine Pankreas der Säugetiere auf zahlreiche Langerhans'sche Inseln verteilt. Das Studium dieses endokrinen Organs wird weiter dadurch kompliziert, daß die einzelne Insel aus Zellen besteht, die verschiedene endokrine Funktionstypen aufweisen. In der vorliegenden Utbersicht werden einige Auswege beschrieben, wie die Überwindung dieser analytischen Probleme zu erzielen ist. $A$ ) Die Feststellung einer engen Beziehung zwischen der Anzahl großer und kleiner Inseln hat es ermöglicht, einfache $\mathrm{Me}-$ thoden für das Messen des totalen Inselvolumens zu entwickeln. Man nimmt die Pankreasschnitte mit gleichen Intervallen und zählt nur die größeren Inseln. Eine lineare Beziehung konnte nachgewiesen werden zwischen dem Gesamtvolumen der Inseln und der Anzahl länglicher Inselstreifen, die man durch ,,scanning" mit parallelen Linien erhält. B) Mit Hilfe von Silberimprägnierung und darauf folgender Granulafärbung dünner Paraffinschnitte wurde versucht, die verschiedenen Typen von Inselzellen zu identifizieren. Für den Erfolg entscheidend war einerseits die Entwicklung einer Methode, die in einigen Zellen eine konsistente Argyrophilie ergab, und anderseits die
Beobachtung, daß sich diese Silberpräzipitate durch Oxydation mit Kaliumpermanganat entfernen ließen. Es ist heute gesichert, daß die Langerhans'schen Inseln $\alpha_{1}$, $\alpha_{2}$ und $\beta$-Zellen enthalten und außerdem noch einige Zellen, die weder im Lichtmikroskop noch im Elektronenmikroskop erkennbare Granula aufweisen. C) Der Einfluß verschiedener Substanzen auf die Insulinfreisetzung wurde unter Verwendung einzelner mikrodissezierter Inseln von obese-hyperglykämischen Mäusen gemessen. Diese in vitro Technik hat nicht nur eine Beschreibung der Insulinsekretion im Verhältnis zum Inselgewicht erlaubt, sondern auch eine Korrelation zwischen der Insulinsekretion und anderen metabolischen Abläufen in den $\beta$-Zellen. Das nach $30 \mathrm{~min}$ freigesetzte Insulin machte ungefähr ein Promille des Trockengewichts der Insel aus oder waniger als ein Prozent des Insulingehaltes der $\beta$-Zelle. Die Insulinsekretion wurde durch Schütteln des Inkubationsmediums erheblich gesteigert. Ein wässeriger Extrakt von $\alpha_{1}$-Zellen diente als effektiver Hemmstoff im Hinblick auf die Freisetzung von Insulin. D) Eine kombinierte in vivo und in vitro Technils hat es ermöglicht, eine Beziohung zwischen glykolytischen Motaboliten in den $\beta$-Zellen und der Insulinfreisetzung festzustellen. Dio gefriergetrockneten Pankreasschnitto wurden mit Formaldehydgasen behandelt und in Bouins Lösung nachfixiert, um die Inselzellen durch Silberimprägnierung und darauf folgende Granulafärbung identifizieren zu können. Die Stimulierung der Insulinfreisetzung mit Sulfonylharnstoffen war in den $\beta$-Zellen mit einer Verminderung des Gehaltes an ATP und Glykogen verbunden. Eine auffallende Anhäufung von Fructose-1.6-diphosphat und anderen glykolytischen Zwischenprodukten oberhalb dieser metabolischen Stufe wurde nachgewiesen, wenn die Insulinfreisetzung entweder durch Adrenalin oder Diazoxid oder nach Ausschaltung von $\mathrm{Ca}^{2+}$ gehemmt worden war. Unsere Resultate deuten auf das Vorhandensein eines limitierenden Schrittes hin, der nicht nur für den Glucoseabbau, sondern auch für die Regulation der Insulinsekretion bedeutungsvoll ist. Dieser Kontrollpunkt könnte mit der Reaktionsfolge: PhosphoglycerinaldehydDehydrogenase und Phosphoglycerat-Kinase identisch sein.

Key-words: a a $_{1}$-ells, a2-cells, ATP, $\beta$-cells, $\mathrm{Ca}^{2}+$, cyclic AMP, diazoxids, epinephrine, fructose-1.6-diphosphate, glucose matabolism, glycolysis, insulin release, islet volume determination, sulphonylurea.
Oscar Minkowski provided the first definite proof of a relationship between the pancreatic gland and diabetes. During the 80 years which have elapsed since his fundamental experiments with totally pancreatectomized dogs (Mering and Minkowski, 1889; Minkows$\mathrm{ki}, 1893$ ) the significance of a normal function of the endocrine pancreas has been well established. As the recipient today of a diabetes award dedicated to the memory of Oscar Minkowski, I feel that nothing would be more appropriate for my prize lecture than some aspects of the pancreatic islets.

It has proved necessary to elaborate special experimental procedures to overcome the analytical difficulties arising from the morphological complexity of the endocrine pancreas. With a total volume of only a few per cent of the whole gland, the endocrine pancreas is dispersed in a great number of islets of Langerhans.
Studies of this organ are further complicated by the fact that the islets are composed of various types of cells representing different endocrine functions. Various methods for studying the endocrine pancreas have been proposed and extensively tested in our diabetes research group during the last 17 years. The more pertinent of these procedures will now be reviewed, and their usefulness illustrated by recapitulating how they have been applied to elucidate various biological problems.

Determination of the volume of the endocrine pancreas

Methods for measuring the volume of the endocrine pancreas have for a long time either been very laborious or have been criticized for involving unjustified mathematical assumptions. The situation changed markedly when it was found that the distribution cur- 
ves expressing the relation between the total islet volume and the islet diameter were symmetrical. This balance between small and large islets was first described in the adult rat by Tejning (1947). From subsequent studies in our laboratory (Hellman, 1959a-c; Hellman et al., 1961) it was concluded that there is a regular arrangement of the endocrine plancreas also in other mammalian species including man. The striking symmetry obtained when the total volume of the endocrine pancreas is plotted against the islet diameter is illustrated in Fig. 1. The shape of the curve shows that

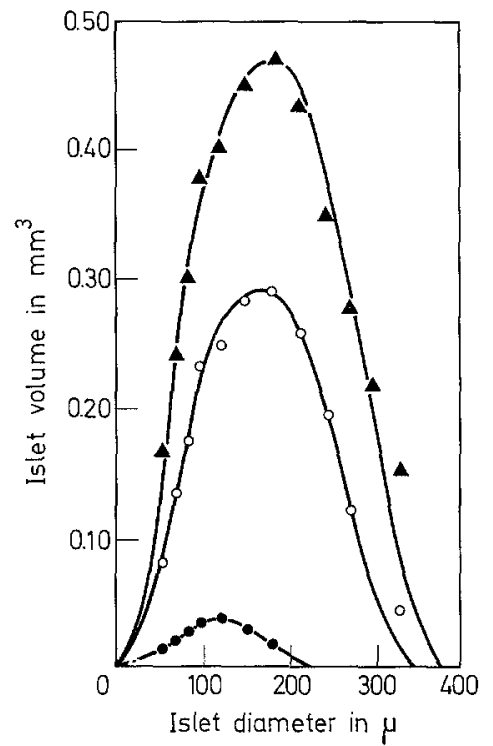

Fig. 1. Volume contribution of islets with different diameters in newborn (O). 100 days old $(O)$ and 480 days old (A) rats. Each curve represents the mean values for 15 animals. There is a striking symmetry at all ages. With the postnatal increase of the total islet volume the curves are broader and their peaks shifted to the right

the main part of the endocrine pancreas consists of medium-sized islets, while the numerous small islets contribute approximately as much to the total islet volume as do the relatively few large islets. With an increased volume of the endocrine pancreas there is a shift in the maximum of the volume curves towards larger islet diameters and consequently also a broadening of the curves (Fig, 1). The appearance of very large islets in sections of pancreas is therefore in itself an indication of an enlarged volume of the endocrine pancreas.

The observation that there is a strictly symmetrical distribution of the endocrine pancreas as well as a regular pattern of islet growth, gave rise to the question whether a mere count of the number of islets would be sufficient for estimating the total volume of the endocrine pancreas (Hellman, 1959d). This was found to be the case. The volume of the endocrine pancreas was a linear function of the number of islets counted in serial pancreatic sections taken at regular intervals. Fig. 2 gives an example of the linear rela- tionship obtained between the total islet volume and the number of islet section surfaces counted with areas exceeding that of a circle $110 \mu$ in diameter. In our attempts to use this relationship for rapid estimation of the volume of the endocrine pancreas, the pancreatic sections were systematically scanned for large islets at a final magnification of $\times 125-150$. The decision whether an islet should be counted or not was facilitated by inserting ellipses of different eccentricities and corresponding to the minimum acceptable islet area in the focal plane of the ocular. This "visual scanning tech-

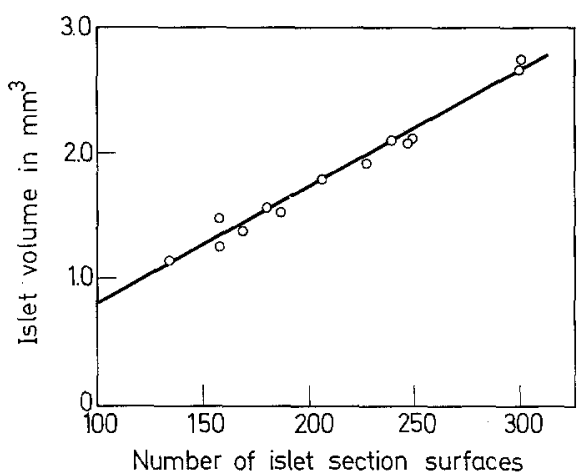

Fig. 2. The relation between the number of islets counted with areas exceeding that of a circle $110 \mu$ in diameter and the total islet volume in 13 adult rats. The pancreatic sections scanned for islets were taken at intervals of $308 \mu$. The values for the total islet volumes here and in Fig. 3 were obtained by multiplying the total areas of all the islets in the sections analysed by the distance between these sections

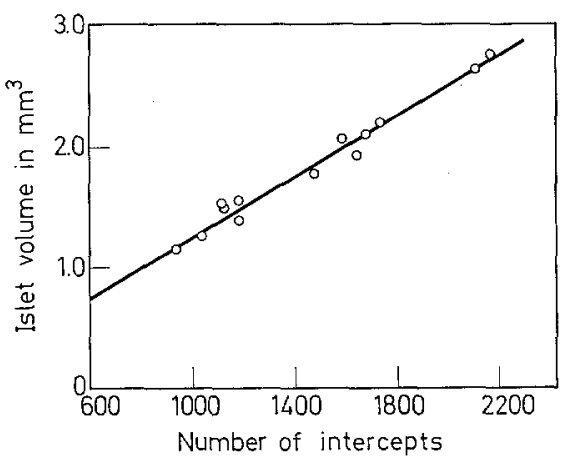

Fig. 3. The relation between the number of islet intercepts longer than $84 \mu$ and the total islet volume in the same animals as shown in Fig. 2. The pancreatic sections were taken at intervals of $308 \mu$, and the distance between the scanning lines was $21 \mu$

nique" has up to now been applied to several sets of experimental conditions (Petersson and Hellman, $1962 \mathrm{a}, \mathrm{b}$; Hellerström, 1963; Hellerström and Hellman, 1963), one of which is illustrated in Table 1. It emerges from this Table that the volume of the endocrine mouse pancreas was increased by more than 100 per cent after inducing obesity by intraperitoneal injections of goldthioglucose. 
As a further consequence of the regular arrangement of the endocrine pancreas, its total volume was also linearly related to the number of long islet intercepts obtained by scanning sections with parallel lines (Brolin and Hellman, 1963). This relationship is exemplified in Fig. 3, using sections from the same pancreatic glands as shown in Fig. 2. If there is satis- granule stains after an initial silver impregnation. Most important for the final success of these attempts was the elaboration of a modified Davenport technique for silver impregnation, which gave a consistent argyrophilia in some islet cells, and the observation that these silver deposits could be removed by oxidation with potassium permanganate (Hellman and Hellerström,

Table 1. Calculation of the totat volume of the endocrine mouse pancreas $\left(\mathrm{mm}^{3}\right)$ from the number of large islet section surfaces (equal to or exceeding the area of a standard circle $110 \mu$ in diameter) in serial pancreatic sections taken at intervals of $308 \mu$. Columns I and II show the numbers of large islets found in duplicate determinations made independently on different sections. The body weight was $29.2 \pm 0.4 \mathrm{~g}$ in the control animals, and $44.4 \pm 1.3 \mathrm{~g}$ in the mice made obese by goldthioglucose

\begin{tabular}{|c|c|c|c|c|c|c|c|}
\hline \multicolumn{4}{|c|}{ Control animals } & \multicolumn{4}{|c|}{ Animals made obese with goldthioglucose } \\
\hline Mouse & \multicolumn{2}{|c|}{$\frac{\text { Counted number of }}{\text { islets }>110 u}$} & \multirow{2}{*}{$\begin{array}{l}\text { Islet } \\
\text { volume } \\
\mathrm{mm}^{3}\end{array}$} & \multirow{2}{*}{$\begin{array}{l}\text { Mouse } \\
\text { No. }\end{array}$} & \multicolumn{2}{|c|}{$\frac{\text { Counted number of }}{\text { islets }>110 \mu}$} & \multirow{2}{*}{$\begin{array}{l}\text { Islet } \\
\text { volume } \\
\mathrm{mm}^{3}\end{array}$} \\
\hline No. & & II & & & & II & \\
\hline 1 & 49 & 63 & 0.67 & 1 & 128 & 114 & 1.40 \\
\hline 2 & 48 & 50 & 0.59 & 2 & 227 & 228 & 2.59 \\
\hline 3 & 64 & 59 & 0.73 & 3 & 62 & 75 & 0.81 \\
\hline 4 & 71 & 70 & 0.83 & 4 & 90 & 108 & 1.15 \\
\hline 5 & 82 & 74 & 0.92 & 5 & 154 & 156 & 1.78 \\
\hline 6 & 57 & 61 & 0.70 & 6 & 152 & 147 & 1.72 \\
\hline 7 & 55 & 55 & 0.66 & 7 & 133 & 135 & 1.54 \\
\hline 8 & 73 & 82 & 0.69 & 8 & 218 & 213 & 2.46 \\
\hline 9 & 68 & 68 & 0.80 & 9 & 217 & 215 & 2.46 \\
\hline 10 & 85 & 70 & 0.91 & 10 & 65 & 66 & 0.78 \\
\hline 11 & 79 & 99 & 1.04 & & & & \\
\hline 12 & 85 & 71 & 0.92 & & & & \\
\hline \multicolumn{3}{|c|}{ Mean volume \pm S.E.M. } & $0.79 \pm 0.04$ & Mean volum & $\pm \mathbf{S} . \mathbf{E}$ & & $1.67 \pm 0.21$ \\
\hline
\end{tabular}

factory staining of the islets against a light exocrine parenchyma, the procedure of counting longer islet intercepts can be developed into an "automatic scanning technique" for determination" of the total islet volume. A microscopical arrangement has been devised for such measurements, in which the blackened islets are projected onto a photomultiplier close behind a diaphragm with a small aperture (Tove et al., 1961). The dark periods during the scanning movements of the substage correspond to the islet intercepts, which are measured and sorted electronically.

Estimation of the total islet volume from the number of large islets or long islet intercepts presupposes knowledge about the coefficients in the appropriate regression equations. It is evident, however, that the important question of whether the total volume of the endocrine pancreas has increased or decreased during an experiment can be statistically evaluated without knowledge of these coefficients.

\section{Classification of the islet cells}

Throughout the years the classification of islet cells has been a matter of much controversy. Since this could at least to some extent be attributed to unsatisfactory techniques, we tried some years ago to develop a procedure for the identification of the islet cells based on restaining of thin paraffin sections of pancreas with
1960; Hellerström and Hellman, 1960). The oxidation step was identical to that used in the initial step of granule staining with chrome-haematoxylin or aldehyde-fuchsin according to Gomori $(1941,1950)$. This means that a given islet cell could first be studied and photographed in a silver impregnated state and then, after removal of the silver, visualized by specific granule stains.

When this procedure was applied to pancreas from different species including man it was found that the islet $\beta$-cells lacked the argyrophil reaction, and that the $\alpha$-cells could be divided into two groups depending on the presence or absence of cytoplasmic argyrophilia (Hellman and Hellerström, 1960, 1961, 1968; Hellerström et al., 1964). The silver-positive $\alpha$-cells were denoted as $\alpha_{1}$-cells and the silver-negative ones as $\alpha_{2}$-cells (Hellerström and Hellman, 1960). Whereas it is well established that the $\alpha_{2}$-cells represent the pancreatic source of glucagon (Petersson and Hellman, 1963; Lundquist et al., 1969), nothing definite can be said about the functional significance of the other type of $\alpha$-cell. The possibility of gastrin production in the $\alpha_{1}$ cells has received much attention (cf. Foa, 1968), and recent immunofluorescent studies support this idea (Lomsky et al., 1969). In reviewing how the existence of two types of pancreatic $\alpha$-cells was first observed, it is necessary to point out the surprising specificity for the $\alpha_{1}$-cells of the modified Davenport technique for 
silver impregnation. It has later been reported that other silver impregnation procedures preferably blacken the $\alpha_{2}$-cells (Grimelius, 1968).

Current views on the cellular composition of the pancreatic islets and the possibilities for classification of their cellular components with silver impregnation and other staining procedures have been summarized in Table 2. In addition to $\alpha_{1}, \alpha_{2}$ and $\beta$-cells there are nowski 1967). In attempting to devise a reproducible system in vitro for studying insulin secretion, we preferred to adhere to the original procedure of isolating islets by free-hand dissection. This decision was prompted not only by a great deal of experience with this particular technique, but also by the assumption that the viability of the $\beta$-cells is best preserved by dissection in a chilled medium devoid of collagenase. The

Table 2. Some characteristics of the four types of islet cells. The presence of argyrophilia or other cytoplasmic staining reactions and discernible granules has been denoted by + . When there are species differences in the staining reaction of the istet cells, this has been indicated by \pm

\begin{tabular}{|c|c|c|c|c|c|c|c|c|}
\hline \multirow[t]{2}{*}{ Cell type } & \multirow{2}{*}{$\begin{array}{l}\text { Secretion } \\
\text { product }\end{array}$} & \multicolumn{2}{|l|}{ Argyrophilia } & \multicolumn{3}{|c|}{ Cytoplasmic staining } & \multicolumn{2}{|l|}{ Granules } \\
\hline & & $\begin{array}{l}\text { Modified } \\
\text { Davenport } \\
\text { technique }\end{array}$ & $\begin{array}{l}\text { Bodian and } \\
\text { Grimelius } \\
\text { techniques }\end{array}$ & $\begin{array}{l}\text { Aldehyde } \\
\text { fuchsin }\end{array}$ & Phloxine & Light green & $\begin{array}{l}\text { Light } \\
\text { microscope }\end{array}$ & $\begin{array}{l}\text { Electron } \\
\text { microscope }\end{array}$ \\
\hline$\alpha_{1}$-cells & Gastrin (?) & + & \pm & - & \pm & \pm & \pm & + \\
\hline$\alpha_{2}$-cells & Glucagon & - & + & - & + & - & $\mp$ & + \\
\hline$\beta$-cells & Insulin & 一 & - & + & - & $\rightarrow$ & + & + \\
\hline Agranular cells & $?$ & - & - & - & \pm & + & - & - \\
\hline
\end{tabular}

also some cells which lack discernible granules both in the light and electron microscope (Falkmer et al., 1964). It seems most appropriate to refrain from using the previous designation of $C, \delta, \varepsilon$ or $X$ cells in particular species in view of the general existence of 4 distinct ty. pes of islet cells. The concept of $\delta$-cells is particularly misleading, since both the $\alpha_{1}$-cells and the agranular cells display the cytoplasmic staining characteristics considered as specific for the $\delta$-cells (Björkman el al., 1966; Boquist, 1967).

\section{The release of insulin from a single microdissected islet}

Techniques in vitro offer considerable advantage over the very complex system of the intact animal in attempts to evaluate how various substances directly influence the mechanisms of insulin release. The approach in vitro has in the past been hampered by the fact that the exocrine pancreas releases enzymes which lyse the secreted hormone. Several procedures have been proposed to overcome or minimize the effect of this proteolytic activity (Bouman, 1960; Mialhe and Meyer, 1963; Malaisse et al., 1967). It seems, however, that the destructive effect of the exocrine parenchyma is best eliminated by studying insulin release in a system with isolated islets. This not only provides for optimal exchange of oxygen and nutrients, but also facilitates correlation of the rate of insulin secretion with the metabolic-events in the $\beta$-cells.

Five years ago a method for free-hand dissection of metabolically-intact islets from the mammalian pancreas was described by Hellerström (1964). Since then, several authors have reported procedures for isolation of islets based either on microdissection (Keen et al., 1965) or sedimentation after collagenase treatment of the pancreas (Moskalewski 1965; Lacy and Kostia- microscopical observations of dissected islets, as well as more sensitive metabolic criteria such as high ATP values (Hellman et al., 1969a; Hellman and Idahl 1969) and a constant rate of oxygen consumption for several hours (Hellerström 1967), support such an idea.

The mouse pancreas was selected as a convenient source of islets with a high proportion of $\beta$-cells. It was possible to isolate very large islets containing more than $90 \% \beta$-cells from animals with the obese-hyperglycaemic syndrome. There is now a great deal of experimental evidence indicating that the enlargement of the islets in these animals only reflects a compensatory hyperplasia of normal $\beta$-cells in response to an increased blood glucose level of extra-pancreatic origin (Hellman, 1965; Stauffacher et al., 1967; Westman, 1968; Lernmark and Hellman, 1969). Normoglycaemia occurs within hours after withdrawal of food from the obesehyperglycaemic mice, and at the same time their degranulated $\beta$-cells become filled with granules. This made it easy to select $\beta$-cells in different states of functional activity for the studies in vitro of the insulin releasing mechanisms.

A schematic outline of the different steps involved in our testing of how different agents affect the release of insulin in vitro is shown in Fig. 4 . Pieces of pancreas were removed and placed in a medium kept at $+2^{\circ} \mathrm{C}$. After dissection, the metabolically-active islets were individually transferred to polypropylene microtubes and incubated for various periods of time at $37^{\circ} \mathrm{C}$. Enough insulin was released from the $\beta$-cells of a single islet to be adequately measured with the double antibody radioimmunological technique of Hales and Randle (1963) using crystalline mouse insulin as standard. After incubation, each islet was placed on aluminium foil and immediately frozen in isopentane chilled to its freezing point with liquid nitrogen. After the islets had been freeze-dried overnight at $-40^{\circ} \mathrm{C}$ 
and $0.001 \mathrm{~mm} \mathrm{Hg}$, they were weighed on a quartz-fibre balance. The technique allows for the first time a description of insulin release in terms of islet weight. Another advantage is that the rate of insulin secretion can be correlated to the content of insulin or to the level of various metabolites in each individual islet (see below). raised from 0.6 to $3.0 \mathrm{mg} / \mathrm{ml}$ (Hellman et al., $1969 \mathrm{~b}$ ). It is also apparent that the hypoglycaemic sulphonylurea compound glibenclamide is a potent stimulator of insulin release from the isolated islets. This unequivocal sulphonylurea effect deserves attention in view of the scarcity of glucagon-producing $\alpha_{2}$-cells in our system in vitro. It has recently been postulated that
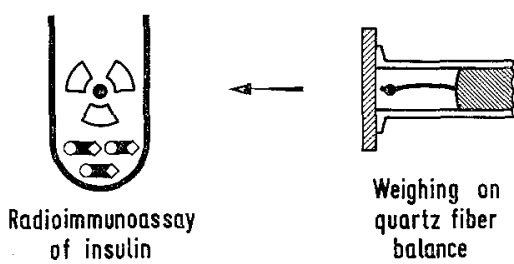
balance

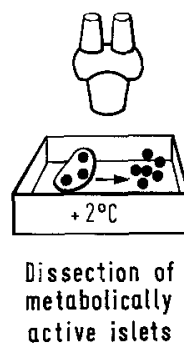

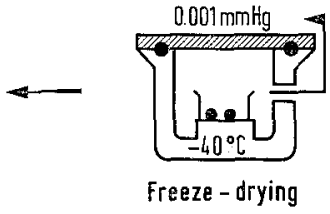
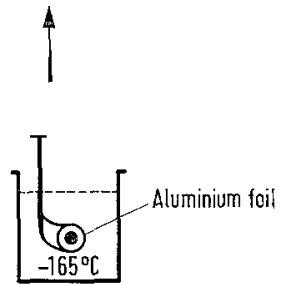

Quick freezing
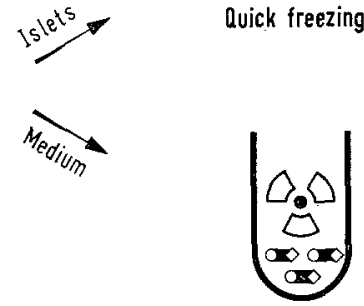

Radioimmunoassay of insulin

Fig. 4. Procedure for testing the effect of various compounds on insulin release from a single islet microdissected from the frosh pancreas of an obese-hyperglycaemic mouse. After incubation, the islet is freeze-dried and weighed on a quartz-fibre balance, and the medium assayed for insulin by a double antibody radioimmunological technique. This makes it possible to describe insulin release in terms of islet weight. After extending the radioimmunological assays to the weighed islets, the amounts of insulin secreted can also be expressed in relation to the $\beta$-cell content of this hormone

A great number of substances have now been tested in our system in vitro with microdissected islets from obese-hyperglycaemic mice. With increasing experience in manipulating the islets, including careful washing and preincubation to remove insulin leaked during the dissection procedure, the amounts of insulin released during $30 \mathrm{~min}$ have been found to be as low as about 1 per thousand of the islet dry weight, or less than 1 per cent of the original content of insulin in the $\beta$-cells. The rate of insulin release could be significantly enhanced by increasing the movements of the incubation medium by shaking. It is tempting to speculate that this potentiation of insulin release imitates the effects of blood circulation through the islets by reducing high levels of insulin in the immediate surroundings of the $\beta$-cells (Hellman, 1968).

An example is given in Fig. 5 of an experiment in which insulin secretion was increased to four times the base line level, when the glucose concentration was inhibition of pancreatic glucagon secretion is essential for the hypoglycaemic action of sulphonylurea com. pounds (Samols etal., 1969). The appreciable sulphonylurea stimulation may further exemplify the advantage of avoiding the use of enzymes in isolation of the islets. As a matter of fact, no stimulatory effect was observed when collagenase-isolated rat islets were exposed to different concentrations of tolbutamide for various periods of time (Lacy et al., 1968).

Our procedure for measuring the amounts of insulin released from a single isolated islet means that an experiment can be performed with minimal volumes of incubation medium. It is thus possible to attain effective concentrations of the compounds to be tested even when these are available in very limited amounts. Fig. 6 shows how a water extract prepared from the $\alpha_{1}$-cells of the pigeon pancreas $-0.3 \mu \mathrm{g}$ freeze-dried $\alpha_{1}$-cells per $50 \mu$ l incubation medium - reduces the amount of insulin released in the presence of $3 \mathrm{mg} / \mathrm{ml}$ 
glucose (Hellman and Lernmark, 1969a, b). This observation provides the first direct evidence that the $\alpha_{1}$-cells contain a substance that inhibits insulin release. Whether this means that the $\alpha_{1}$-cells are biologically important as local regulators of insulin secretion is a matter for further study. In any case, the inhibitory substance in the $\alpha_{1}$-cells represents a potential source

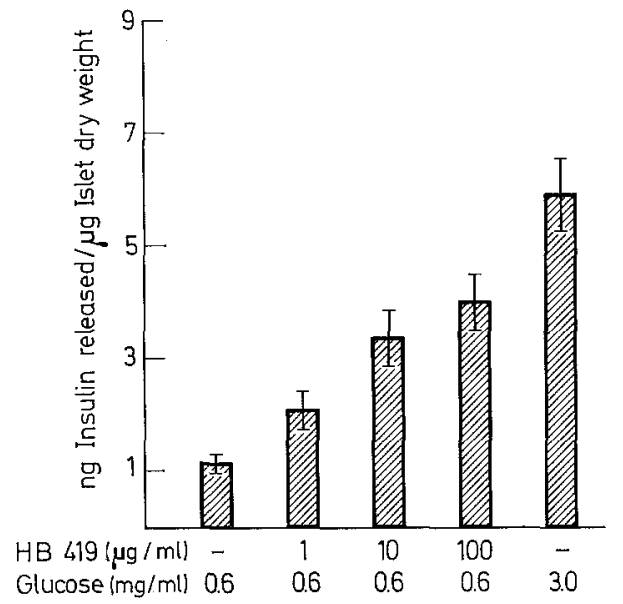

Fig. 5. Insulin release from microdissected islets of obesehyperglycaemic mice after raising the glucose concentration from 0.6 to $3.0 \mathrm{mg} / \mathrm{ml}$, or adding various concentrations of HB 419 (glibenclamide) to a bicarbonate medium containing the low glucose concentration. The bars denote $\mathrm{ng}$ insulin released per $\mu \mathrm{g}$ islet dry weight during an incubation period of $30 \mathrm{~min}$, and represent the mean values \pm S.E.M. for 12 animals

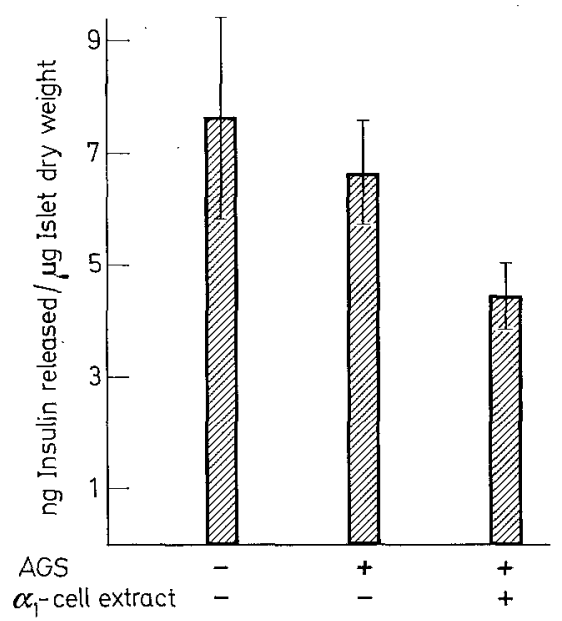

Fig. 6. The effect of an extract of pigieon $\alpha_{1}$-cells on insulin release from microdissected islets of obese-hyperglycaemic mice. The islets were incubated for 30 minutes in a bicarbonate buffer supplemented with $3 \mathrm{mg} / \mathrm{ml}$ of glucose. The $\alpha_{1}$-cell extract was tested at a concentration of about $6 \mu \mathrm{g} / \mathrm{ml}$ in the presence of rabbit anti-glucagon serum (AGS). The AGS was present in a final dilution of $1: 10$, which is equivalent to a binding capacity of $74 \%$ for $100 \mathrm{ng}$ porcine glucagon. The bars denote ng insulin released per $\mu \mathrm{g}$ islet dry weight and represent the mean values \pm S.E.M. for 13 animals of error in attempts to interpret how various agents directly influence the $\beta$-cell function in the proposed system, as well as in others employed for studies of insulin release.

\section{Measurements of glycolytic intermediates and cofactors in the pancreatic $\beta$-cells}

Evidence has been presented for the view that glucose must be metabolized in the pancreatic $\beta$-cells to be effective as a trigger for insulin release (Coore and Randle, 1964). This makes it reasonable to assume that knowledge of the $\beta$-cell levels of glycolytic intermediates and cofactors and their changes with alterations of the functional state might aid in locating the control points in the process of insulin secretion. In attempting to pursue such a research program, we found it necessary to complement the previously described model for measuring how various substances affect insulin release by handling the pancreatic islets from the obese-hyperglycaemic mice as outlined in Fig. 7 .

Islet material was obtained in two ways. The upper left part of Fig. 7 illustrates how pieces of pancreas were rapidly removed and plunged into isopentane chilled to its freezing point $\left(-165^{\circ} \mathrm{C}\right)$ by liquid nitrogen. In the following steps frozen pancreatic sections, $20 \mu$ thick, were cut in a cryostat and freeze-dried overnight. Some of the freeze-dried sections were selected for staining of the islet cells after fixation in formaldehyde vapours and refixation in Bouin's solution. This was usually done by direct staining of the $\beta$-cells with aldehyde-fuchsin. The alternative of demonstrating all kinds of islet cells by the procedure of restaining after initial silver impregnation with the modified Davenport technique (see above), also proved to give excellent results after refixation of freeze-dried pancreas sections. Examination of the stained sections made it easier to isolate portions of $\beta$-cells from the remaining and untreated freeze-dried sections by free hand dissection under a stereomicroscope. After the $\beta$-cell samples had been weighed on a quartz-fibre balance, they were transferred to polypropylene microtubes or Teflon wells (cf. Matschinsky et al., 1968) for further analyses. The lower part of Fig. 7 shows the alternative procedure of analyzing islets which have been microdissected from the fresh pancreas of obese-hyperglycaemic mice, and incubated for various periods of time. The initial steps were identical with those employed in our system in vitro for measuring insulin release, and have therefore already been described in connection with Fig. 4 .

The metabolite to be measured was employed to oxidize or reduce a pyridine nucleotide with the aid of the appropriate auxillary enzymes. This commonly used system for analysis was combined with measurements of the pyridine nucleotides by enzymatic cycling and fluorimetry as described by Lowry et al., (1961). In the cycling system the oxidized or reduced pyridine 
nucleotides serve as catalysts of an enzymatic oxidation-reduction cycle, and the rate of the reaction is taken as a measure of the nucleotide. This technique provides a surprising sensitivity for quantitative analyses. With a single cyeling step Matschinsky et al. (1968) measured as little as $10^{-15}$ moles of various recent experiments performed in our laboratory. It was, for example, possible to demonstrate (Hellman et al., $1969 \mathrm{a}, \mathrm{b})$ that hypoglycaemic sulphonylurea compounds markedly reduce the ATP content of the microdissected islets (Fig. 8). This reduction was not a simple consequence of energy consumption during

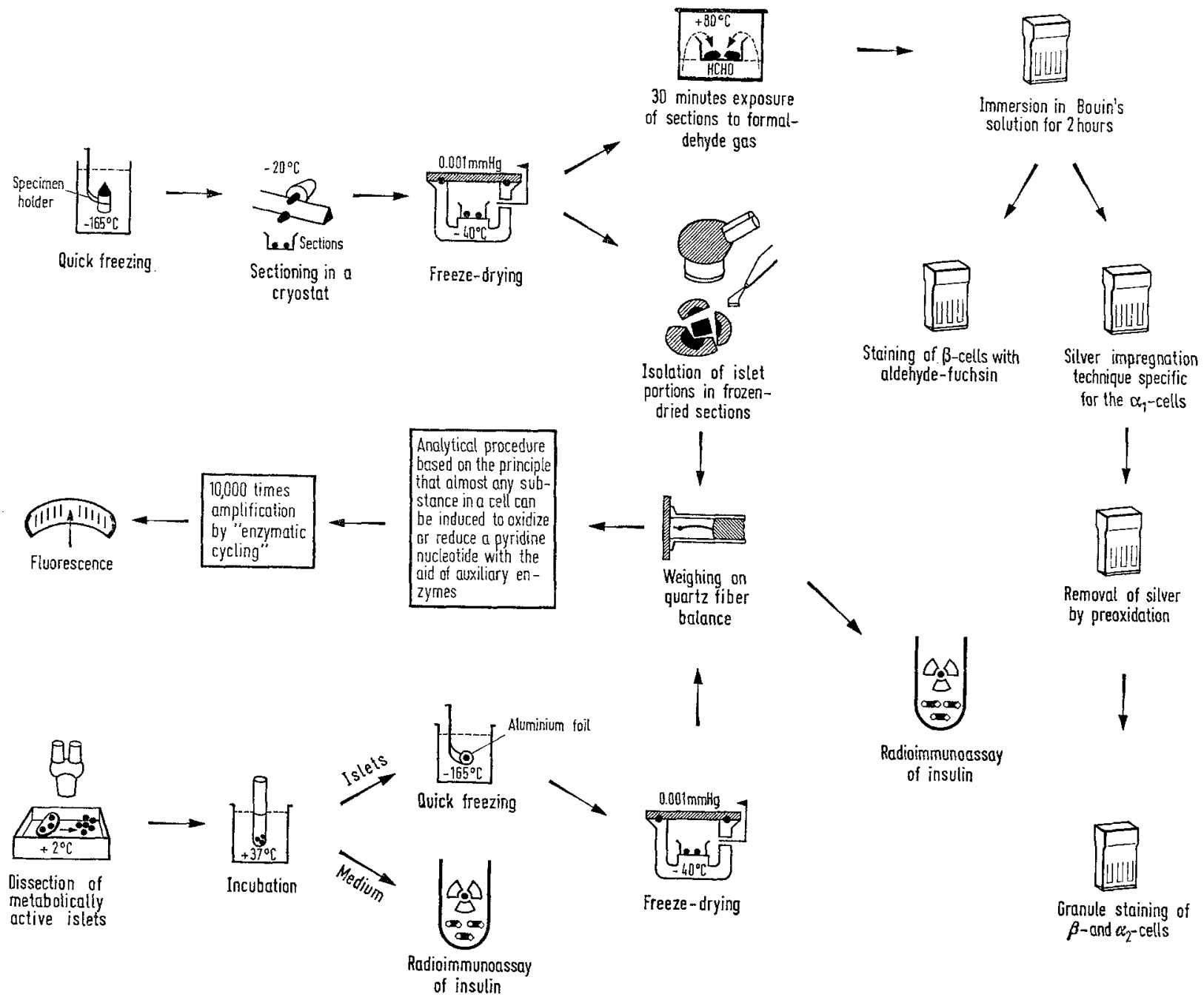

Fig. 7. The alternative ways of dissecting and handling the islet material used for analyses of the $\hat{\beta}$-cell levels of glycolytic intermediates and cofactors. The dissection in freeze-dried pancreatic sections (upper part) makes it possible to isolate pure $\beta$-cell samples from different mammals, as checked in adjacent sections taken for restaining after initial silver impregnation. The initial steps in the alternative procedure of using islets microdissected from the fresh pancreas of obese-hyperglycaemic mice (lower part) are identical with those described in Fig. 4, and allow a correlation of the metabolite levels to the rate of insulin secretion. In both cases the freeze-dried material is weighed on a quartz-fibre balance before being analyzed for various metabolites with the aid of auxillary enzymes and enzymatic cycling

glycolytic intermediates. Lowry (1964) postulated that double cycling would make it possible to measure $10^{-18}$ moles; $i$.e approximately the amount of product that a single molecule of the average enzyme would produce in one hour.

The usefulness of the proposed scheme for exploring the insulin secreting mechanisms was obvious from the process of insulin secretion. In the presence of several other compounds known to induce definite changes in the rate of insulin secretion (epinephrine, diazoxide or dibutyryl-3,5-cyclic AMP), the $\beta$-cell content of ATP remained unaffected (Hellman and Idahl, 1969). It seems most likely that the sulphonylurea effect on ATP is due to an uncoupling of oxida- 
tive phosphorylation. This mechanism of action has been well documented by studies in vitro of the rat liver and diaphragm (Pentillä, 1966; De Beer and De Schepper, 1967), and is also consistent with the observation of an increased oxygen uptake when the microdissected islets are exposed to hypoglycaemic sulphonylurea compounds (Stork et al., 1969). A release of oxida-

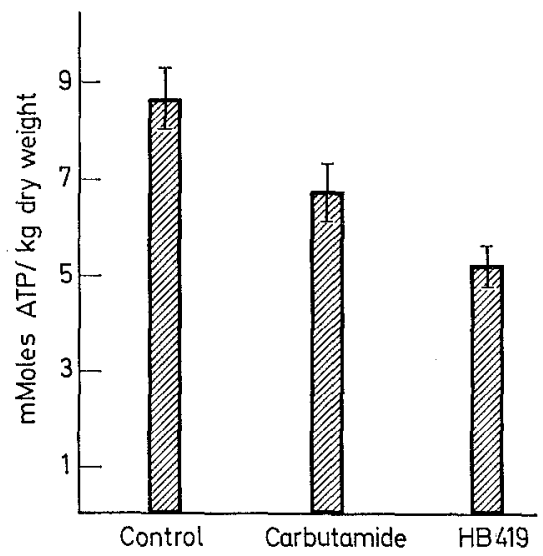

Fig. 8. ATP content in microdissected islets from obesehyperglycaemic mice after 45 minutes incubation with $200 \mu \mathrm{g} / \mathrm{ml}$ of carbutamide or $50 \mu \mathrm{g} / \mathrm{ml}$ of HB 419 (glibenclamide) in a bicarbonate medium containing $0.6 \mathrm{mg} / \mathrm{ml}$ of glucose. The bars denote mmoles ATP per kg dry weight, and represent the mean values \pm S.E.M. for $9-12$ animals

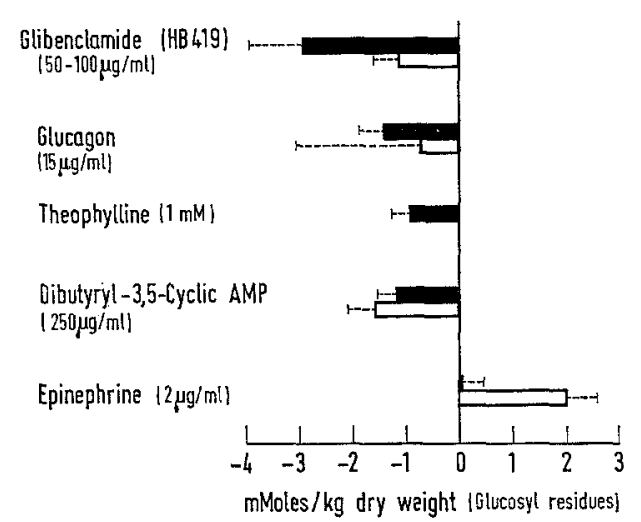

Fig. 9. Changes of the glycogen content (mean values \pm S.E.M.) after exposing microdissected islets from obese-hyperglycaemic mice to various compounds known to affect insulin release. The black bars refer to experiments performed in bicarbonate buffers containing 0.6 $\mathrm{mg} / \mathrm{ml}$ of glucose, and the white bars to those performed in the presence of $3.0 \mathrm{mg} / \mathrm{ml}$ of glucose. The incubation time was 60 minutes in the glucagon experiments and 15 minutes when $100 \mu \mathrm{g} / \mathrm{ml}$ of $\mathrm{HB} 419$ (glibenclamide) was tested in the low glucose medium. In the remaining cases the incubation time was 30 minutes. All compounds were tested on islets from $8-14$ animals. Each animal has been used as its own control by calculating the individual changes in mmoles glucosyl residues per kg dry weight.

tive phosphorylation probably implies that increased amounts of ADP, AMP and inorganic phosphate will be available for $\beta$-cell metabolism. Such a modification of the "phosphate potential" is known to stimulate the glycolytic flux in several types of animal cells ( $c f$. Scrutton and Utter, 1968), and might consequently provide the glucose metabolite supposed to trigger insulin release. This idea was supported by our observation that hypoglycaemic sulphonylurea compounds deplete the $\beta$-cell stores of glycogen (Hellman and Idahl, 1969). It is evident from Fig. 9 that the sulphonylurea compounds have the ability to mobilize the $\beta$-cell glycogen in common with several other insulin secretagogues. The inhibitory effect of epinephrine on insulin secretion was, on the other hand, associated with a significant increase in the amounts of $\beta$-cell glycogen.

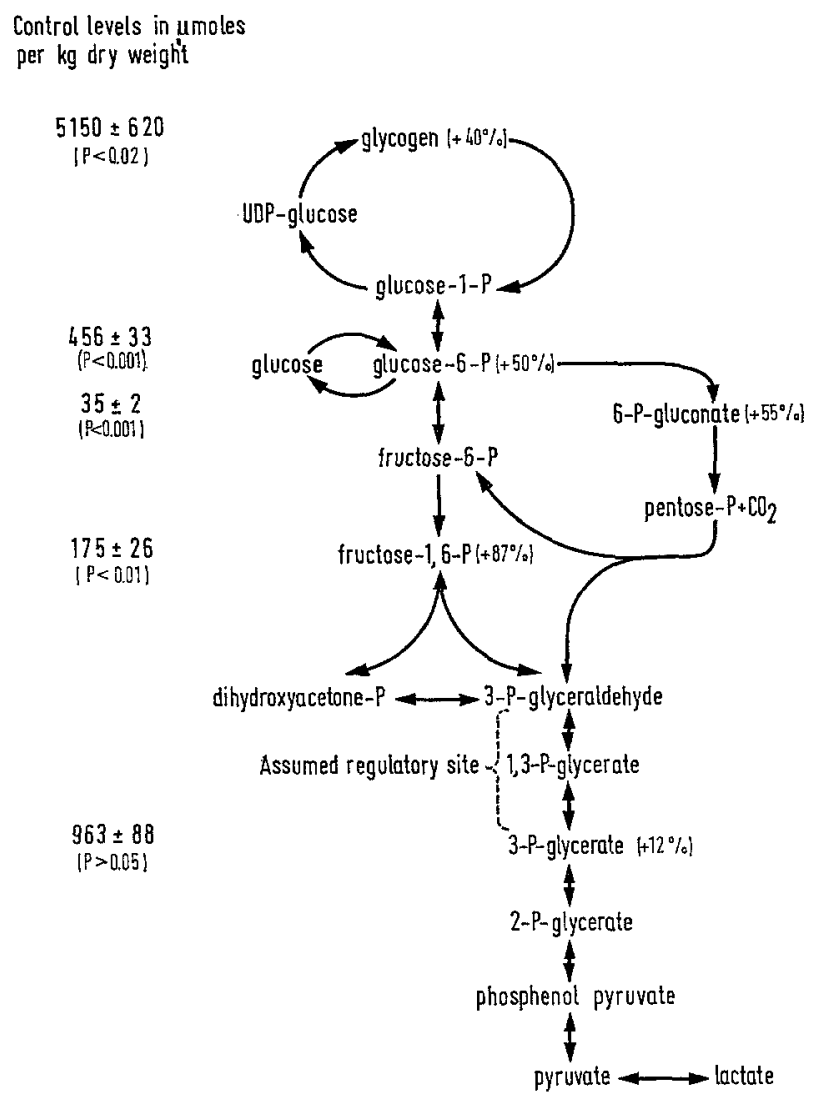

Fig. 10. Percentage changes of various glycolytic intermediates after $30 \mathrm{~min}$ exposure of microdissected islets to $2 \mu \mathrm{g} / \mathrm{ml}$ of epinephrine in a bicarbonate buffer containing $3.0 \mathrm{mg} / \mathrm{ml}$ of glucose. Each intermediate has been measured in islets from $6-14$ obese-hyperglycaemic mice. The level of the controls has been given to the left of the respective metabolite as $\mu$ moles per $\mathrm{kg}$ dry weight (mean values \pm S.E.M.). There was a significant accumulation of fructose-1,6-diphosphate as well as of the other intermediates above this metabolic stage, when insulin secretion was inhibited with epinephrine. The levels of 3-phosphoglycerate should be regarded as provisional until confirmed with a combination of auxillary enzymes other than that used in the analyses performed up to now.

Epinephrine has been reported to inhibit the formation of 3,5-cyclic AMP by stimulation of the $\alpha$-adrenergic receptor sites of the $\beta$-cells (Turtle and 
Kipnis, 1967). It was apparent from our further studies of the microdissected islets from the obese-hypergly. caemic mice that the effect of epinephrine on the glucose metabolism of the $\beta$-cells was not restricted to an increase of glycogen. There were signs of both a decreased glycolytic flux and a striking accumulation of fructose-1,6-diphosphate, as well as of other intermediates of glucose above this metabolic stage (Fig. 10). A similar accumulation of metabolites was observed when insulin release was inhibited with diazoxide or by omission of $\mathrm{Ca}^{2+}$ from the incubation medium. The latter observation might indicate that the effects of ions on insulin secretion is also mediated by glucose metabolism. Milner and Hales (1969) have recently postulated that a late event in stimulation of insulin secretion involves uptake of $\mathrm{Ca}^{2+}$ in the $\beta$-cells by a sodium-dependent mechanism.

The response of the $\beta$-cells exposed to epinephrine makes it reasonable to assume that there is a ratelimiting step in the degradation of glucose of direct significance for the regulation of insulin release. This control site might be identical with the sequence phosphoglyceraldehyde dehydrogenase-phosphoglycerate kinase. The demonstration in other tissues of a strong product inhibition by 1,3-phosphoglycerate suggests that the first reaction is strongly dependent upon the subsequent kinase reaction, even when phosphoglyceraldehyde dehydrogenase is present in high concentrations (Velic and Furfine, 1963). The regulatory significance of this enzyme sequence has been well established in red blood corpuscles, where the membrane-bound phosphoglycerate kinase represents a point at which active cation transport influences the glycolytic rate (Parker and Hoffman, 1967). It should be pointed out that the kinetic characteristics of the proposed two-enzyme complex not only are consistent with a stimulation by $\mathrm{Ca}^{2+}$ (Mahler and Cordes, 1966), but also explain how the sulphonylurea modification of the "phosphate potential" (see above) via increased amounts of $\mathrm{ADP}$ and inorganic phosphate can stimulate the process of insulin release.

\section{References}

Björkman, N., Hellerström, C., Hellman, B., Petersson, B.: The cell types in the endocrine pancreas of the human fetus. Z. Zellforsch. 72, 425-445 (1966).

Boquist, L.: Morphology of the pancreatic islets of the non-diabetic adult Chinese hamster Cricetulus griseus. Acta Soc. Med. upsalien. 72, 331 -344 (1967).

Bouman, P.R.: Release of insulin from isolated rat pancreas in vitro. Acta endocr. (Kbh.) 35, 560-567 (1960).

Brolin, S., Hellman, B.: New methods for determination of the pancreatic islet volume. Diabetes 12, 62-65 (1963).

Coore, H.G., Randle, P.J.: Regulation of insulin secretion studied with pieces of rabbit pancreas incubated in vitro. Biochem. J. 93, 66-78 (1964).

De Beer, I., De Schepper, P.J.: Metabolic effects of hypoglycemic sulfonylureas. In vitro effect of sulfonylureas on cell-free protein synthesis and energy metalbolism in rat tissues. Biochem. Pharmacol. 16, 23552367 (1967).
Falkmer, S., Hellman, B., Voigt, G. E.: On the agranular cells in the pancreatic islet tissue of the marine teleost Cottus scorpius. Acta path. microbiol. scand. 60, 47-54 (1964).

Foa, P.P.: Glucagon. Ergebn. Physiol. 60, 142-219 (1968).

Gomori, G.: Observations with differential stains on human islets of Langerhans. Amer. J. Path. 17, 395-406 (1941).

-- Aldehyde-fuchsin: A new stain for elastic tissue. Amer. J. clin. Path. 20, 665-666 (1950).

Grimelius, L.: A silver nitrate stain for $\alpha_{2}$ cells in human pancreatic islets. Acta Soc. Med. upsalien. 73, 243-270 (1968).

Hales, C.N., Randle, P.J.: Immunoassay of insulin with insulin-antibody precipitate. Biochem. J. 88, 137-146 (1963).

Hellerström, C.: The influence of pregnancy and lactation on the endocrine pancreas of mice. Acta Soc. Med. upsalien. 68, 17-28 (1963).

- A method for the microdissection of intact pancreatic islets of mammals. Acta endocr. (Kbh.) 45, 122-131 (1964).

- Effects of carbohydrates on the oxygen consumption of isolated pancreatic islets of mice. Endocrinology 81, 105-112 (1967)

- Hellman, B.: Some aspects of silver impregnation of the islets of Langerhans in the rat. Acta endocr. (Kbh.) $35,518-532(1960)$.

- The islets of Langerhans in yellow obese mice. Metabolism 12, 527-536 (1963).

- - Petersson, B., Alm, G.: The two types of pancreatic A-cells and their relation to the glucagon secretion. In: The Structure and Metabolism of the Pancreatic Islets I, pp. 117-130. Eds. Brolin, S.E., Hellman, B., Knutson, H. Oxford: Pergamon Press 1964.

Hellman, B. : The volumetric distribution of the pancreatic islet tissue in young and old rats. Acta endocr. (Kbh.) 31, 91-106 (1959a).

- The frequency distribution of the number and volume of the islets of Langerhans in man. 1. Studies on nondiabetic adults. Acta Soc. Med. upsalien. 64, 432-460 (1959b).

- Actual distribution of the number and volume of the islets of Langerhans in different size classes in nondiabetic humans of varying ages. Nature (Lond.) 184, $1498-1499(1959 \mathrm{c})$.

-- A method for rapid estimation of the islet volume in the rat pancreas based on counting instead of measuring the islet section surfaces. Acta path. microbiol. scand. $47,21-34(1959 \mathrm{~d})$.

- Studies in obese-hyperglycemic mice. Ann. N.Y. Acad. Soi. 131, 541-558 (1965).

- Histochemical observations of the $\beta$-cells during insulin secretion. Acta Diab. Latina 5 (suppl. 1), 446-457 (1968).

-- Brolin, S., Hellerström, C., Hellman, K.: The distribu. tion pattern of the pancreatic islet volume in normal and hyperglycemic mice. Acta endocr. (Kbh.) 36, $609-616$ (1961).

- Hellerström, C.: The islets of Langerhans in ducks and chickens with special reference to the argyrophil reaction. Z. Zellforsch. 52, 278-290 (1960).

- - The specificity of the argyrophil reaction in the islets of Langerhans in man. Acta endocr. (K bh.) 36, 22-30 (1961).

- - Histology and histophysiology of the islets of Langerhans in man. In: Handbuch des Diabetes Mellitus, pp. 89-118. Ed. Pfeiffer, E.F. München: J.F. Lehmanns 1968.

- Idahl, L.A.: Control of ATP levels in stimulated pancreatic $\beta$-cells. Acta Diab. Latina 6 (suppl. 1), $597-611(1969)$. 
- Danielsson, A.: Adenosine triphosphate levels of mammalian pancreatic $\beta$-cells after stimulation with glucose and hypoglycemic sulfonylureas. Diabetes 18, $509-516(1969$ a).

- - Tjälve, H., Danielsson, А., Lernmark, A.: Beobachtungen zum Wirkungsmechanismus des hypoglykämisch wirksamen Sulfonylharnstoff-Präparates HB 419. Arzneimittel-Forsch. 19, 1472-1476 (1969b).

- Lernmark, A.: Inhibition of the in vitro secretion of insulin by an extract of pancreatic $\alpha_{1}$-cells. Endocrinology $84,1484-1488$ (1969a).

- - A possible role of the pancreatic $\alpha_{1}$ - and $\alpha_{2}$-cells as local regulators of insulin secretion. In: The Structure and Metabolism of the Pancreatic Islets II. Eds. Falkmer, S., Hellman, B., Täljedal, I.B. Oxford: Pergamon Press (In press) $1969 \mathrm{~b}$.

Keen, H., Sells, R., Jarrett, R.J.: A method for the study of the metabolism of isolated mammalian islets of Langerhans and some preliminary results. Diabetologia 1, 28-32 (1965).

Lacy, P.E., Kostianovsky, M.: Method for the isolation of intact islet of Langerhans from the rat pancreas. Diabetes 16, 35-39 (1967).

- Young, D.A., Fink, C.J.: Studies on insulin secretion in vitro from isolated islets of the rat panereas. Endocrinology 83, 1155-1161 (1968).

Lernmark, $\AA$., Hellman, B. : The $\beta$-cell capacity for insulin secretion in microdissected pancreatic islets from obesehyperglycemic mice. Life Sci. (Part II) 8, 53-59 (1969).

Lomsky, R., Langr, F., Vortel, V.: Immunohistochemical demonstration of gastrin in mammalian islets of Langerhans. Nature (Lond.) 223, 618-619 (1969).

Lowry, O.H.: Microanalysis for histochemical purposes. In: Second International Congress of Histo- and Cytochemistry, pp. 62-69. Eds. Schiebler, T.H., Pearse, A.G. E., Wolff, H.H. Berlin: Springer 1964.

- Passonneau, J.V., Schulz, D.W., Rock, M.K.: The measurement of pyridine nucleotides by enzymatic cycling. J. biol. Chem. 236, 2746-2755 (1961).

Lundquist, G., Brolin, S. E., Unger, R.H., Eisentraut, A.: The cellular origin of glucagon. In: The Structure and Metabolism of the Pancreatic Islets II. Eds. Falkmer, S., Hellman, B., Täljedal, I.B. Oxford: Pergamon Press (In press) 1969.

Mahler, H.R., Cordes, E.H.: Biological Chemistry. New York: Harper \& Ron 1966.

Malaisse, W., Malaisse-Lagae, F., Wright, P.H.: A new method for the measurement in vitro of pancreatic insulin secretion. Endocrinology 80, 99-108 (1967).

Matschinsky, F.M., Passonneau, J.V., Lowry, O.H.: Quantitative histochemical analysis of glycolytic inter. mediates and cofactors with an oil well technique. J. Histochem. Cytochem. 16, 29-39 (1968).

Mering, J., von, Minkowski, O.: Diabetes mellitus nach Pankreasextirpation. Naunyn-Schmiedebergs Arch. exp. Path. Pharmak. 26, $371-387$ (1889).

Mialhe, P., Meyer, V.: Sécrétion d'insuline par le pancréas de rat in vitro. C.R. Acad. Sci. (Paris) 253, 1861-1863 (1963).

Milner, R.D.G., Hales, C.N.: Ionic mechanisms in the regulation of insulin secretion. In: The Structure and Metabolism of the Pancreatic Islets II. Eds. Falkmer, S., Hellman, B., Täljedal, I.B. Oxford: Pergamon Press (In press) 1969.

Minkowski, O.: Untersuchungen über den Diabetes Mellitus nach Extirpation des Pankreas. Naunyn-Schmiedebergs Arch, exp. Path. Pharmak. 31, 85-189 (1893).

Moskalewski, S.: Isolation and culture of the islets of Langerhans of the guinea pig. Gen. comp. Endocr. 5, $342-353$ (1965).

Parker, J.C., Hoffman, J.F.: The role of membrane phosphoglycerate kinase in the control of glycolytic rate by active cation transport in human red blood cells. J. gen. Physiol. 50, 893-916 (1967).

Pentillä, L.M.: Effect of insulin, chlorpropamide and tolbutamide on the metabolism of branched chain amino acids. Ann. Med. exp. Fenn. 44, suppl. 11 (1966).

Petersson, B., Hellman, B.: The pancreatic islet tissue in mice with obesity by goldthioglucose. Acta path. microbiol. scand. 55 401-406 (1962a).

- - Long-term effects of restricted caloric intake on pancreatic islet tissue in obese-hyperglycemic mice. Metabolism 11, 342-348 (1962 b).

- - Effects of long term administration of glucagon on the pancreatic islet tissue of rats and guinea pigs. Acta endoer. (Kbh.) 44, 139-149 (1963).

Samols, E., Tyler, J.M., Mialhe, P.: Suppression of pancreatic glucagon release by the hypoglycemic sulfonylureas. Tancet $1969 \mathrm{I}, 174-176$.

Scrutton, M.C., Utter, M.F.: The regulation of glycolysis and glucogenesis in animal tissues. Ann. Rev. Biochem. 37, 249-302 (1968).

Stauffacher, W., Lambert, A.E., Vecchio, D., Renold, A. F.: Measurements of insulin activities in pancreas and serum of mice with spontaneous ("obese" and "New Zealand obese") and induced (goldthioglucose) obesity and hyperglycaemia, with considerations on the pathogenesis of the spontaneous syndrome. Diabetologia 3, 230-237 (1967).

Stork, H., Schmidt, F.H., Westman, S., Hellerström, C.: Action of some hypoglycaemic sulphonylureas on the oxygen consumption of isolated pancreatic islets of mice. Diabetologia 5, 279-283 (1969).

Tejning, S.: Dietary factors and quantitative morphology of the islets of Langerhans. Acta med. scand. suppl. 198 (1947).

Tove, P.A., Brolin, S., Hellman, B.: Scanning microscope for photoelectric data evaluation. Rev. Sci. Instrum. 32, 1343-1346 (1961).

Turtle, J.R., Kipnis, D.MI.: An adrenergic receptor mechanism for the control of cyclic $3^{\prime} 5^{\prime}$ adenosine monophosphate synthesis in tissues. Biochem. biophys. Res. Comm. 28, 797-802 (1967).

Velic, S.F., Furfine, C.: Glyceraldehyde 3-phosphate dehydrogenase. In: The Enzymes, 7, pp. 243-273. Eds. Boyer, P.D., Lardy, H., Myrbäck, K. New York: Academic Press 1963.

Westman, S.: The endocrine pancreas of old obese-hyperglycemic mice. Acta Soc. Med. upsalien. 73, 81-89 (1968). 